\title{
LA MEMORIA DE JULIO DIAMANTE
}

\author{
Francisco GUTIÉRREZ CARBAJO \\ UNED-Madrid
}

\section{RESUMEN}

El artículo es un recorrido por el mundo de los recuerdos y de las creaciones de uno de los nombres más significativos y menos estudiados del cine español contemporáneo. Con el objetivo de recuperar la memoria histórica, se presenta la trayectoria política y personal de su padre, Julián Diamante Cabrera, y de su abuelo, Julio Diamante Menéndez, que fueron encarcelados por defender la legalidad establecida. Se analiza igualmente el papel de la memoria en la trayectoria política y artística de Julio Diamante Stihl, con especial atención a su cinematografía, pero con referencias a otras manifestaciones, como el teatro.

Palabras clave: cine, teatro, Julio Diamante, memoria, franquismo.

\begin{abstract}
This paper centres on the memories and creations of one of the most important and less studied filmmakers of the contemporary Spanish cinema. It also presents the political and personal career of his father, Julián Diamante Cabrera, and his grandfather, Julio Diamante Menéndez, who were imprisoned for defending the established legality.

Finally, the paper focuses on the role of the memory in Julio Diamante's political and artistic career, with special attention to his movies, but with references to other manifestations, as the theatre.
\end{abstract}

Key words: cinema, theatre, Julio Diamante, memory, Franco's regime.

\section{MEMORIAS DE LA NIÑEZ. SU PADRE Y SU ABUELO ENCARCELADOS}

Si pueden compartimentarse y dividirse los contenidos que alberga nuestra mente, la memoria del franquismo se inicia para el director de cine, guionista y escritor Julio Diamante en los días en los que es conducido a visitar a su padre y a su abuelo, prisioneros en las cárceles franquistas. Son los años finales de la década 
de los treinta y del comienzo de los cuarenta del siglo pasado. El niño no puede entender que se encuentren privados de libertad y no admite el argumento de que están encarcelados por haber sido idealistas: «Mi madre, por el deseo de evitarme problemas, me decía, a manera de explicación, que ambos eran unos "idealistas". Pero yo no acababa de comprender que el ser idealista mereciera castigo» (Diamante, 2007: 12).

En el desarrollo de la historia y en la esfera de la ética -en contraste con lo que sucede a veces en el campo de la neurología- no hay olvidos benignos, y por eso Julio Diamante no puede obviar ni ética ni históricamente esos primeros recuerdos de su niñez. Como dice Engels, hay que estar al día, es decir, hay que oír la voz de la historia, y Julio Diamante, seguidor, en la teoría y en la práctica, de la izquierda hegeliana, mantiene esa consigna, que en él se traduce en seguir la voz de sus ascendientes más directos. Su voz y su memoria se convierten, así, en testimonio y denuncia de algunos de los hechos más execrables de la historia reciente.

En este devenir de la historia de casi nuestros días, ¿qué delitos pueden imputárseles a su padre y a su abuelo para hurtarles los bienes más preciados del ser humano?, ¿qué faltas han cometido para privarles del derecho de la libertad, para separarlos del ámbito de los suyos, para retirarlos de la convivencia con el resto de los ciudadanos en la sociedad civil, que es lo que, según Aristóteles, nos define como humanos? La respuesta no puede ser más sencilla y contundente: sus únicos delitos fueron su actitud de patriotas comprometidos con la historia de su pueblo, su lealtad a los principios que el pueblo soberano se había otorgado y su fidelidad a la legalidad vigente. Franco y el resto de los generales que se sublevaron -y quienes los apoyaron- fueron los conculcadores de esa legalidad.

Las tesis de que hay lecturas o interpretaciones distintas de la historia difícilmente pueden admitirse cuando se trata de hechos tan recientes y tan rigurosamente analizados por los más prestigiosos investigadores. Otra cosa es la manipulación malévola o la falsificación de la historia, como se ha puesto de manifiesto en numerosas ocasiones. En el caso que nos ocupa, es un buen ejemplo de manejo y de tergiversación de los hechos la sentencia del Consejo de Guerra Permanente del 24 de noviembre de 1941, que «por el procedimiento sumarísimo de urgencia» se sigue contra el padre de Julio Diamante, «el procesado Julián Diamante Cabrera, de 34 años, natural y vecino de Madrid, casado, ingeniero, hijo de Julio y Matilde». La sentencia está firmada por el Presidente Félix Navajas García, los vocales Carlos Rodríguez, Joaquín Fernández Repeto, Bartolomé Parra Navarro y por el vocal-ponente Jesús García Gutiérrez.

La perversidad tergiversadora de la sentencia hace responsable del levantamiento a los «rojos», y como uno de los protagonistas de la insurrección se considera al ingeniero de Caminos, Canales y Puertos Julio Diamante:

Anales, 21, 2009, pp. 67-84 
RESULTANDO: probado y así lo declara el Consejo que el procesado Julián Diamante Cabrera, afiliado a la Asociación de Amigos de la Unión Soviética desde el año 1932 en que se fundó, y al Sindicato Nacional de Arquitectura e Ingeniería (afecto a la UGT) en Marzo de 1936, al iniciarse la rebelión roja prestaba su servicio como Ingeniero en los Canales de Lozoya y desde los primeros momentos manifestó su entusiasmo por esta causa, tocándose con mono y portando pistola (Diamante, 2007: 8).

La insurrección, por tanto, la iniciaron los «rojos», los fieles a la legalidad constitucional y no un bando de traidores a la República, capitaneados por unos generales facciosos.

La historia ha documentado de forma fehaciente cómo se inició la rebelión militar y quiénes fueron los militares responsables del alzamiento. La voz del gran bajo negro Paul Robeson también nos ha legado el testimonio de estos nombres, aunque su profecía no se cumplió: «Los cuatro generales / que se han alzado / para la Nochebuena / serán ahorcados. / Franco, Sanjurjo, Mola / y Queipo de Llano» (Diamante, 2007: 21).

Pero la sentencia del año 1941 contra el padre de Julio Diamante reitera descaradamente esta falsedad: «Fue nombrado Presidente del Comité de Vecinos de la casa en que vivía por su probada afección a la causa rebelde y es el más caracterizado de los vecinos afectos a esta Causa».

Por si lo expuesto no fuese suficiente, en el considerando se insiste en que «los anteriores hechos revisten los caracteres de delito de AUXILIO A LA REBELIÓN MILITAR, previsto y penado en el párrafo $1^{\circ}$ del art. 240 del C.J.M., de cuyo delito es autor el inculpado por participación directa y material en los hechos» (Diamante, 2007: 8). Ateniéndose a instrucciones y órdenes del año 1940, se condena al procesado «a la pena de doce años y un día de reclusión menor y accesorios legales correspondientes».

La sentencia es un ejemplo entre las miles que se dictaron. En muchos casos se llevaron a cabo ajusticiamientos y en otros muchos fueron asesinadas numerosas personas sin haberse realizado el juicio. Un testigo nada sospechoso de izquierdismo como el conde Ciano anotaba en su visita a España en la inmediata posguerra: «Todavía hay muchas ejecuciones. Sólo en Madrid entre 200 y 250 diarias; en Barcelona, 150; en Sevilla, una ciudad que nunca estuvo en manos de los rojos, $80 \ldots$.. El ministro de relaciones internacionales italiano no paró mientes en el campo, donde el Generalísimo iba a resolver el problema agrario por algunos lustros: en muchos pueblos se fusiló, por las buenas, a la cuarta parte del vecindario (Aub, 1969:169). Otros murieron en las cárceles y presidios, como el abuelo de Julio Diamante, que fallece en el año 1945.

En la memoria de Julio Diamante han quedado fijados para siempre y con una increíble nitidez estas experiencias de finales de los años treinta y de princi- 
pios de los cuarenta, con mayor fuerza aun que en el recuerdo del coronel Aureliano Buendía de Cien años de soledad de García Márquez «aquella tarde remota en que su padre lo llevó a conocer el hielo». En Julio Diamante quedan muy atrás las imágenes del niño jugando en La Caleta de su Cádiz natal, el recuerdo de los días en que se trasladan de la sierra a Madrid, e igualmente lejanos en el tiempo, pero siempre presentes en la memoria la experiencia de la guerra en la capital del Estado, el ruido atronador de los aviones y el estampido de los obuses, que podían escucharse incluso desde los refugios improvisados. La casa de los Diamante, en la calle Cristóbal Bordiu, no quedaba lejos del frente y Julián Diamante relata cómo una granada de artillería estalló en un piso vecino. Ya al final de la guerra, Julio Diamante recuerda «el fuego cruzado entre casadistas -Casado, Miaja y Besteiro soñaban ingenuamente que era posible pactar con Franco una Rendición digna- y comunistas que, fieles a Negrín, querían resistir. Unos y otros, parapetados en sendos esquinazos de la calle. Una imagen: al final de la guerra las contraventanas de metal que tenían nuestras ventanas, acabaron hechas un colador por los balazos y la metralla» (Diamante, 2007: 25).

No obstante, lo que la memoria de Julio Diamante ha cristalizado de los primeros momentos del franquismo son, como se ha apuntado, los encuentros con su abuelo y con su padre en la cárcel. Más cruel que el proceso de su padre, Julián Diamante Cabrera, fue el de su abuelo, Julio Diamante Menéndez. Miembro de Izquierda Republicana, de la que fue durante cierto tiempo Presidente, Julio Diamante Menéndez cursó la carrera de Ingeniero de Caminos. Durante la Segunda República y la guerra ocupó el puesto de Jefe del Circuito Nacional de Carreteras, cargo de gran responsabilidad que le llevó a acompañar al Gobierno cuando se traslada de Madrid a Valencia. Aunque al parecer, podía haber partido justo antes de finalizar el conflicto, tomó la decisión de permanecer en España y fue hecho prisionero.

En la prisión mantuvo siempre la serenidad y la firmeza este hombre, que, según Julio Diamante, fue la persona que realmente más le conmocionó en su vida: «las visitas a mi padre, quizá por ser más joven y bromista, me impresionaban menos» (Diamante, 2007: 38).

Julio Diamante reproduce algunos textos del libro Republicanos de catacumbas de Régulo Martínez, en los que se hace referencia a esa firmeza y serenidad, así como a su inmensa bondad. Régulo Martínez perteneció a Izquierda Republicana y años más tarde desempeñó el cargo de presidente honorario de Acción Republicana Democrática (ARDE), y nos relata en su libro cómo Julio Diamante intentó moderar a los incontrolados en los primeros meses de la guerra:

...Vi cruzar por la galería (de Gobernación) a don Julio Diamante, personalidad destacada de Izquierda Republicana y con él me convenía cambiar impresiones, ya 
que fue él quien intentó con mi ayuda precisamente librar de las manos de los incontrolados que por aquel entonces -me refiero a los primeros meses de la guerrapropinaban con indiscutible pasión los llamados paseos, tomándose lo que ellos se creían justicia, a la catalana... (Martínez, 1977, apud Diamante, 2007: 38).

Régulo Martínez observa que el masón de categoría y protestante desde muy joven, Julio Diamante, tanto por su categoría de los llamados «firmes especiales» como por su responsabilidad bien administrada como dirigente republicano, derrochó el bien a su alrededor, sin distinción de colores ni de ideologías.

Estas cualidades las subrayan incluso sus acusadores ante los tribunales franquistas. Las distintas declaraciones, efectuadas todas ellas en agosto de 1939, la única culpa que le achacan a Julio Diamante Menéndez es la de ser «persona de izquierdas». A pesar de ello fue condenado a la pena de veinte años y un día de prisión. Las condiciones tan precarias y penosas de la cárcel debilitaron su salud, y cuando ya se encontraba gravemente enfermo, el médico de la cárcel solicitó en varias ocasiones que fuese hospitalizado, solicitudes que no resultaron atendidas. Ya en situación de extrema gravedad fue trasladado para ser operado a un hospital, donde murió el 14 de febrero de 1945.

La férrea maquinaria de la justicia franquista debía de estar tan ocupada en la represión de los que no fueran afectos a su causa, que no encontraba tiempo para llevar un registro exacto de los muertos y desaparecidos. Ello explicaría lo inexplicable de la última actuación del régimen de Franco en relación con Julio Diamante Menéndez: el día 27 de febrero de 1945, o sea, trece días después de la muerte, una nota oficial le informaba de que ya sólo le faltaban por cumplir once años, dos meses y veintiséis días, «dejando por consiguiente extinguida la condena dicho reo el 9 de marzo de 1956» (Diamante, 2007: 39).

Tampoco fue fácil la vida de Julián Diamante Cabrera, hijo de Diamante Menéndez y padre de Julio Diamante Stihl. Julián Diamante Cabrera, Ingeniero de Caminos, Canales y Puertos, trabajó durante los primeros años de la II República en Cádiz. Más tarde fue trasladado a Madrid, al Canal de Lozoya, hoy Canal de Isabel II. Simpatizaba, según nos recuerda Julio Diamante, con diversas formaciones de izquierdas -Izquierda Republicana, Partido Socialista, Partido Comunista y UGT-, pero no pertenecía a ningún partido político. Identificado con el progreso que representaba la República, se opuso a la sublevación y colaboró desde su especialidad con los poderes legítimamente constituidos. Intervino en las fortificaciones de Somosierra, en la defensa de Madrid, y más tarde fue nombrado Mayor-Jefe del Batallón de Puentes no 3, que mereció en la batalla del Ebro, por su heroico comportamiento, la Medalla al Valor Colectivo.

Junto a estas acciones realizadas por su padre, la memoria de Julio Diamante relata otros momentos de las memorias de Julián Diamante, como la caída del Cuartel de la Montaña, la formación de las BOF, Brigadas Obreras del Frente; el 
arriesgado corte de agua que realizó en el Clínico ocupado por los insurrectos, la construcción de los puentes en el río Ebro... La memoria de su padre termina cuando, tras ser detenido en San Sadurní de Noya, lo llevan prisionero camino del campo de Avilés. Después recorrerá las cárceles de El Coto de Gijón, Conde de Toreno, Yeserías, Santa Rita y la Colonia Penitenciaria de Toledo, para «extinguir su pena por el trabajo». Ya antes de la condena, en junio de 1939 había sido separado y dado de baja en el Cuerpo de Ingenieros.

En 1945 se halla en situación de «libertad vigilada», «observando una conducta moral no vituperable». A partir de esa fecha inicia una verdadera lucha por reintegrarse al Cuerpo de Ingenieros de Caminos, Canales y Puertos. Se trata de un proceso kafkiano plagado de infinidad de solicitudes y recursos, que concluye el 23 de julio de 1971, cuando el Consejo de Ministros acuerda la readmisión en el Cuerpo. En 1973 Julián Diamante es nombrado Jefe del Negociado de Normas de Materiales e Instrucciones Técnicas. Ha logrado reintegrarse al Cuerpo de Ingenieros, pero le ha costado treinta y cuatro años. Poco después, el 20 de marzo de 1976 causa baja «por cumplirse la edad reglamentaria para la jubilación forzosa» (Diamante, 2007: 37).

\section{LA UNIVERSIDAD Y LAS LUCHAS ESTUDIANTILES. DIAMANTE STIHL EN LA CÁRCEL}

Cuando todavía Julián Diamante se encuentra inmerso en ese largo proceso para su reintegración plena a la vida civil, su hijo Julio Diamante, que ha iniciado la carrera de Medicina en la Universidad Complutense, se hace eco del «redoble de conciencia» que agitaba la vida pública española y se incorpora a los movimientos estudiantiles, en otro duro proceso encaminado a reimplantar en el país los más elementales derechos democráticos.

Julio Diamante participa muy activamente en el Congreso de Escritores Jóvenes y en el Homenaje laico a Ortega y Gasset:

El fallecimiento de Ortega y Gasset, en octubre de 1955 y su entierro seguido por más de un millar de estudiantes recorriendo el centro de Madrid, fue como el signo anunciador de una nueva época. El 18 de noviembre, el rector, Laín Entralgo, presidía en el Paraninfo de la Universidad el homenaje a la memoria del desaparecido, entre ovaciones de los estudiantes. No era un acto aislado; la inquietud crecía en los medios universitarios. Coincidiendo con ella se elaboró el proyecto de reunir un Congreso de universitarios escritores jóvenes, que contó con la aquiescencia de Laín (Tuñón de Lara, 1988: 10, 285).

En el boletín preparatorio de este congreso se critica ya a «quienes eliminan por decreto de la comunidad cultural española todo lo que no tiene aspecto ortodoxo». El poder franquista reacciona contra estos intentos aperturistas; clausura las revistas Alcalá, Ateneo, Ínsula e Índice y suspende el anunciado congreso. M. 
Cianfarra, corresponsal en Madrid del New York Times, publica en este periódico un sondeo realizado por el Instituto de Opinión Pública entre cuatrocientos estudiantes, de los que el $85 \%$ se manifestaba opuesto al gobierno, el 95\% a la jerarquía militar, el 70\% pensaba que la política social de la Iglesia no era aceptada por el pueblo y el $65 \%$ opinaba que se terminaría imponiendo en España un régimen de tipo socialista (Tuñón de Lara, 1988: 10, p. 285).

En enero de 1956, Julio Diamante firma con otros muchos una carta dirigida al ministro de Educación, recabando la convocatoria de un congreso nacional de estudiantes, formado por delegados libremente elegidos bajo el control de los claustros de profesores. Dionisio Ridruejo (1976: 335) ha recordado que presidió la reunión en la que fue aprobada la carta firmada por los estudiantes, que a su vez Ruiz Giménez remitió a Fernández Cuesta, pero el ministro falangista no acusó respuesta. Los estudiantes rechazan a los candidatos oficiales del SEU propuestos para las elecciones, toman la Facultad de Derecho de la Complutense y por primera vez, después de la guerra civil, realizan una manifestación por las calles de San Bernardo y Gran Vía, hasta llegar al Ministerio de Educación en Alcalá. Julio Diamante participa en esta manifestación y recuerda cómo el 9 de febrero de 1956 los falangistas celebran el Día del estudiante caído, se producen enfrentamientos entre los falangistas y los estudiantes, y un militante de las Falanges Juveniles de Franco, Miguel Álvarez, cae gravemente herido por una bala que procedía de sus propios correligionarios. Estos incidentes reactivan los instrumentos de represión y de coacción. El Consejo de Ministros, reunido en sesión urgente, informa que «aplicará la ley con rigor», y entre las medidas represoras comienza una ola de detenciones y son encarcelados Dionisio Ridruejo, Javier Pradera, Miguel Sánchez-Mazas, Ramón Tamames, José M. Ruiz Gallardón, Gabriel Elorriaga, Enrique Mújica, Jesús López Pacheco, etc. Julio Diamante logra escapar y se marcha primero a Valencia y después a Lérida. Como la policía franquista sigue acosándolo, regresa a Madrid y se presenta en la Dirección General de Seguridad en la Puerta del Sol. Cuando le dice su nombre a uno de los agentes de la Brigada Político Social, éste sale al pasillo y grita con voz castrense: « ¡Ya tenemos a Diamante...!». Por allí habían pasado y habían sido interrogados varios dirigentes estudiantiles...; en el interrogatorio de Julio Diamante le preguntan si le gustan Unamuno, Ortega y Kafkant (sic).

De la Puerta del Sol pasa a la cárcel de Carabanchel, y en la séptima galería coincide con Dionisio Ridruejo, Ramón Tamanes, etc. Julio Diamante comparte celda con un estudiante de Islandia, que había sido arrestado al dictarse el estado de excepción. De Islandia no había representación diplomática en España, y se encarga de los trámites la embajada de Suecia, que logra su puesta en libertad. Cuando el islandés es liberado ocupa su puesto Enrique Múgica en la celda de 
Julio Diamante. En la séptima galería se imparten charlas entre los detenidos, se realizan proyecciones de cine y Julio Diamante pinta un cuadro al óleo sobre el escenario de estas proyecciones.

Resultan ilustrativas para las memorias del franquismo las biografías elaboradas por la Dirección General de Seguridad de los dirigentes estudiantiles Ramón Tamames, Enrique Múgica, Javier Pradera, Fernando Sánchez Dragó y Julio Diamante Stihl.

Enrique Múgica Hertzog es considerado como el cerebro del grupo, y se detalla su origen hebreo-alemán, se afirma que sus padres y abuelos fueron fusilados por los nacionalistas y que su familia tiene una peletería muy buena en San Sebastián: «apareció en la Facultad de Derecho de Madrid en el curso 1953-54, procedente de Francia. Decía abiertamente que era comunista, pero que hacía falta acuerdo, armonía y comprensión entre todas las tendencias ideológicas» (Tuñón de Lara, 1989: 12, 572).

Como uno de los más destacados colaboradores de Enrique Múgica es considerado Ramón Tamames, del que se dice que es hijo de un médico prestigioso, con muy buena cabeza y capacidad de trabajo, «ateo y formado en el Liceo Francés». Se añade más adelante que durante los dos últimos cursos ha estado al frente de la sección de intercambio del SEU de Derecho, organismo que ha funcionado admirablemente, según la policía, y ha enviado a muchos estudiantes a campos de trabajos y universidades extranjeras. Esta circunstancia fue aprovechada por Tamames y Múgica, según el informe gubernativo, «para enviar sus elementos a ambientes protestantes alemanes y comunistas franceses en contacto con las aulas marxistas de los lugares de trabajo».

Fernando Sánchez Dragó es presentado como antiguo alumno del Pilar, «ateo rabioso y blasfemo recalcitrante, aunque con una especie de buena intención subjetiva muy especial. Es un chico muy joven, dieciocho años a lo sumo, que tendría un gran placer publicando un clásico libelo subversivo, lleno de poemas más o menos pornográficos...» (Tuñón de Lara, 1989: 12, 574).

En esta galería de personajes retratados por la policía, Julio Diamante es asociado al grupo comunista, sin afiliación partidista, pero asegurando que es utilizado por los comunistas porque es un «exaltado y buen conductor de masas». En conversaciones con Julio Diamante, éste no se siente molesto por las calificaciones peyorativas que recibe de la policía, precisamente porque provienen de la policía: «verdadero mal sujeto, hasta el punto de que los institucionistas lo desprecian, pero fue él quien llevó la dirección práctica del homenaje estudiantil a Ortega y arrastró la gente hasta el cementerio. Ha estudiado en el Escorial, probablemente bachillerato. Parece ser que estudia Medicina» (Tuñón de Lara, 1989: 574). 
Julio Diamante Sithl estudió, en efecto, hasta cuarto curso de Medicina, pero luego se inclinó por el mundo del audiovisual, graduándose en la Escuela de Cine. Se ajusta a la verdad el informe policial cuando afirma que fue el encargado de la dirección del homenaje laico a Ortega. En dicho informe se detallan con minuciosidad los preparativos de la celebración, y el propio Julio Diamante admite que lo expuesto coincide en su mayor parte con lo que sucedió en la realidad. Un grupo de poetas institucionistas y comunistas, dos o tres días después de la muerte de Ortega, «imprimió una esquela sin cruz invitando al acto», que reunió a unos dos mil alumnos en el patio posterior de la sede universitaria de San Bernardo. Acudieron «gentes de todos los matices y había abundantes chicas de Filosofía que llevaban unas flores». La reunión tenía un carácter totalmente estudiantil, como nota de protesta contra el claustro oficialmente establecido, que no dedicaba un homenaje público al Maestro. En seguida empieza a desempeñar un papel destacado Julio Diamante:

Una vez reunida la gente, sin saber nadie qué iba a pasar, salió a escena Julio Diamante Stihl, acompañado de Pacheco, ambos del grupo comunista, que se pusieron a leer trozos de las obras de Ortega que hiciesen resaltar el contraste con la situación actual. El grupo de los simpatizantes de la Institución, los verdaderos orteguianos, asentía a todo [...] Desde el principio se personó en el patio el Decano de la Facultad de Derecho, señor Torres López. En calidad de Decano de la Facultad de Derecho no podía ser ajeno a un acto multitudinario en centro de su jurisdicción. Tampoco podía dar su asentimiento total a aquello, ni oponerse, que hubiera resultado inoportuno e impopular [...] Lo más molesto que se leyó fue un trozo de Ortega en el que se dice que se coge la Religión como sustituto salvado cuando no se tienen ideas para moverse en la vida" (Tuñón de Lara, 1989: 12, 577-578).

Ya en la calle y cuando la gente no sabe muy bien qué hacer, Julio Diamante y López Pacheco comienzan a gritar: «iAl cementerio, al cementerio.... !», con lo que unos seiscientos chicos -según los informes de la policía- se fueron detrás de la cabecera de la manifestación. Salieron a la calle de San Bernardo, continuaron por la Gran Vía hasta Callao, bajaron por Preciados hasta Sol, y luego, por el viejo Madrid y el Rastro, fueron al cementerio de San Isidro. Julio Diamante sigue en su función de director del acto:

Diamante Stihl, que era la voz cantante y llevó a la gente por las calles que quiso, impuso silencio total para que no se diese el espectáculo del patio de San Bernardo, en el que la gente aplaudía a los oradores motivando las protestas de Torres López que gritaba indignado: ¡No se aplaude, no se aplaude! Al llegar a Sol impuso también Diamante a los manifestantes un orden más o menos longitudinal para dar más impresión de orden.

Una vez en el cementerio se dirigieron todos a la tumba de Ortega. Volvieron a repetirse los discursos y las lecturas de los trozos del difunto, repitiéndose igualmente los gestos melodramáticos del orador de San Bernardo, que acabó diciendo, con un puñado de tierra en las manos, que aquello era Castilla y que Castilla ha 
muerto. Entonces Diamante dio por terminado el acto (Tuñón de Lara, 1989: 12, 578).

Se produjeron murmullos de desorientación ya que algunos opinaban que lo más oportuno sería rezar un padrenuestro. Diamante, Pacheco, Múgica y los demás directivos inician la retirada, y ante la pregunta de algunos chicos sobre si se rezaba una oración, Diamante contestó que «cada uno hiciese lo que quisiera y que el acto había acabado».

El gobierno franquista se siente molesto con esta ceremonia y la considera una clara manipulación política orquestada por los comunistas, utilizando a Ortega como bandera. Según el informe gubernativo, el propio Julio Diamante lo consideraba así: «Diamante llegó a decir que "por fin el viejo iba a servir para algo". Ante una severa mirada de Múgica suavizó la expresión como dando a entender que no era eso exactamente lo que había querido decir de Ortega» (Tuñón de Lara, 1989: 12, 579).

Manifestaciones de rebeldía cívica por parte de los universitarios seguirían produciéndose en las décadas siguientes, con asambleas, manifestaciones y protestas, y con la consiguiente represión, encarcelamiento o separación de profesores de sus cátedras hasta que se consigue el restablecimiento de la democracia. Julio Diamante abandona la carrera de Medicina por la de Cinematografía y, junto a su labor de director y guionista cinematográfico, hay que destacar también su actividad teatral y su producción poética.

\section{EL CREADOR Y DIRECTOR JULIO DIAMANTE: CINE, TEATRO...}

Las películas dirigidas por Julio Diamante y las obras de teatro que ha puesto en escena constituyen muestras ejemplares de la memoria del franquismo: en unos casos como denuncia explícita de una situación injusta y en otros como manifestaciones paródicas de unos usos sociales determinados por esa misma situación.

Julio Diamante termina los estudios de Dirección en la Escuela Oficial de Cinematografía en 1961, y tres años más tarde es nombrado profesor de dicha institución, actividad que mantiene hasta la clausura del centro en 1975. Del año 1972 al 1989 dirige con gran tino la Semana de Cine de Autor de Benalmádena, que alcanza resonancia internacional. Como docente, ha impartido cursos -además de en la EOC- en la Cátedra de Cinematografía de Valladolid y en las universidades de Burgos, Complutense, Cádiz y en el Ateneo de Madrid.

En su labor de dirección destacan, entre otros, los largometrajes siguientes: Los que no fuimos a la guerra (Cuando estalló la paz) (1962), seleccionado por el Festival de Venecia; Tiempo de amor (1964), seleccionado por los festivales de Valladolid, Premio a la mejor película en lengua española, Premio al mejor 
guión, Mención de honor de la Federación Internacional de Prensa Cinematográfica y de la Federación de Cine-Clubs, Locarno, etc.; El arte de vivir (1965), seleccionado por el Festival de Berlín; Tempo di charleston (1969), coproducción con Italia; Helena y Fernando (Neurosis), coproducción con Francia; Sex o no sex (1974) y La Carmen (1976) declarada de Especial Interés Artístico. Ha dirigido también cortos y mediometrajes, como Antes del desayuno (1955), El proceso (1955), Organillo (1958), Velázquez y lo velazqueño (1961). Este último documental fue rodado con motivo de la exposición organizada por el Museo del Prado en el tercer centenario del fallecimiento del pintor y resultó premiado en el festival de Berlín y en el de los Nuevos Valores Cinematográficos (Las Palmas de Gran Canaria).

Para televisión ha dirigido los filmes Vicente Escudero (1968), Un hombre con amor propio, El cupé rojo, Marta, La dama recelosa, Barro en las uñas, El otro compañero, La sanción, El puente (1973) para la serie Stop, y sus adaptaciones de El obispo leproso (1974) y Martín Fierro (1975). Ha elaborado los guiones de sus películas, en algunos casos en colaboración con Elena Sáez, y han sido premiados por el Ministerio de Cultura sus guiones En torno al ángel caído (1992), Cuchillo negro (1997) y La calle de la libertad (1998). También ha escrito para TVE los guiones de Avatar, El vigilante, La falsa amante, Historia de un año, Carmilla, El Castillo de Merret, Lokis, La leyenda del caballero de Olmedo y Los niños buenos.

En el campo del teatro, las obras que ha puesto en escena constituyen una buena muestra de su insobornable compromiso con la política y con el arte: destacan entre ellas, La máquina de sumar, de Elmer Rice; Espectros, de Ibsen; Woyzzeck, de Georg Büchner; Los enanos colgados de la lluvia, de Martín Iniesta; Lázaro, de Obey; El tintero y Las viejas difíciles, de Carlos Muñiz; El cuerpo, de Lauro Olmo; Mirandolina (La locandiera), de Goldoni, y la ópera La Médium, de Gian-Carlo Menotti. Para la radio ha escrito las series El teatro a través de sus mejores obras, Los mejores cuentos e Historia y estética de la música afroamericana. Ha sido jurado en los festivales internacionales de Valladolid, Bilbao, San Sebastián, Las Palmas, Tarifa, Huesca, Estrasburgo, Nantes y Thonon (Francia), Leipzig (Alemania), Bérgamo (Italia), así como de la Crítica Internacional CIDALC, de la Federación Internacional de Cine-clubs y de los Premios Buñuel. Diamante ha publicado, además, libros de homenaje a expresiones musicales como el blues y el cante jondo, que son también expresiones poéticas (Diamante, 2004). Ha colaborado en publicaciones nacionales e internacionales como CinémAction, L'Europa Letteraria, Primer Acto, Nuestro Cine, etc.

La memoria del franquismo queda reflejada en muchas de las creaciones y de las actividades señaladas. Quizá uno de los ejemplos más claros sea el filme Los que no fuimos a la guerra (1961). La película, interpretada, entre otros, por 
José Isbert, Félix Fernández, Agustín González, Julia Caba Alba y Gracia Morales, es una adaptación bastante libre de la obra del mismo título de Wenceslao Fernández Flórez.

Aparte de los problemas económicos, la película sufrió diversas mutilaciones impuestas por la censura franquista. A pesar de que la acción transcurre en 1914, los organismos oficiales estimaron que el cineasta trataba de criticar mediante alusiones la guerra civil. La primera medida tomada por los censores del Régimen fue prohibir el título de la película, que pasó a llamarse Cuando estalló la paz, título que podría juzgarse de carácter paródico, y que a Julio Diamante no le acaba de convencer, quizá por el eslogan que vendría luego de los veinticinco años de paz.

A pesar de ser cercenada y de las dificultades con las autoridades gubernativas, la película fue seleccionada oficialmente por la Mostra Internazionale d'Arte Cinematográfica de Venecia, festival que había rechazado todos los títulos propuestos por los organismos oficiales españoles. En Venecia, la crítica y el público la acogieron muy favorablemente, aunque ello no impidió que en España continuase sufriendo una interminable sucesión de peripecias. Cuando finalmente pudo ser proyectada, habían transcurrido cuatro años y sufrido más de media docena de cortes.

La novela Los que no fuimos a la guerra de Fernández Flórez, publicada en el año 1930, exploraba las repercusiones de la Primera Guerra Mundial en la española y neutral ciudad de Iberina a través de la división que se establece en su provinciana sociedad entre francófonos y germanófilos. No hay que olvidar que este debate también se libró entre los intelectuales españoles, dividiéndolos entre los aliadófilos (Ortega y Gasset, Azaña, Pérez de Ayala) y los germánofilos (Pío Baroja, Jacinto Benavente...).

El texto de Fernández Flórez ofrece enormes posibilidades que Julio Diamante supo aprovechar, con las correspondientes reelaboraciones y actualizaciones. El cineasta logra, así, convertir la escisión que se abre en la cerrada sociedad de Iberina motivada «por una guerra que sólo le tocaba indirectamente, en una representación metafórica de una sociedad que, como la española a principios de los años sesenta, si bien estaba lejos de haber superado el drama fratricida escenificado ya hacía un cuarto de siglo, también albergaba en su interior a varias generaciones formadas por "los que no fueron a la guerra" (Zunzunegui, 2005:152). El profesor Santos Zunzunegui ha abordado con rigor el soberbio trabajo de adaptación realizado por Julio Diamante y ha analizado, entre otros aspectos, la nueva reubicación conceptual del personaje principal. En este ejemplo singular de la memoria del franquismo, «Diamante acierta a desbordar los límites del punto de partida literario para ofrecer un retrato singular de algunos 
de los problemas de una sociedad en la que, como en la nuestra, a comienzos de los años sesenta, resonaba todavía el lejano eco del estallido de una paz edificada sobre el silencio de media España» (Zunzunegui, 2005: 159).

Como en Los que no fuimos a la guerra, también desempeña el papel de protagonista en Tiempo de amor (1965) Agustín González, que aquí encarna a Alfonso. Lo acompañan en el reparto, entre otros, Julia Gutiérrez Caba, en el papel de Elvira; Enriqueta Carballeira, en el de María; Julián Mateos, en el de Servando y Lina Canalejas en el de Pilar.

La película Tiempo de amor está integrada por tres historias diferentes: $1^{\text {a }}$ ) una pareja de novios decide romper con la castidad; $2^{a}$ ) una joven descubre que el hombre con el que quiere mantener una relación es un rufián y $3^{a}$ ) un matrimonio trata de mantener la felicidad a través de las pequeñas cosas de la vida cotidiana. En la primera de estas historias, Elvira y Alfonso, novios desde hace diez años, esperan casarse cuando Alfonso gane unas oposiciones, que se le resisten, convocatoria tras convocatoria. Al llegar el momento de la oposición, Alfonso nervioso se retira del examen, y ese mismo día rompen la castidad que, durante tantos años y tan celosamente, se han esforzado en guardar. En la segunda historia, María, empleada de unos grandes almacenes conoce a un apuesto sudamericano, pero más tarde este galán de novela rosa dejará al descubierto su verdadera naturaleza grosera y despótica. En la tercera historia, el matrimonio compuesto por Pilar y José lucha por conservar su amor a través de las dificultades con las que van abriéndose camino en la vida cotidiana.

Las tres historias, unidas por el tema amoroso, están también articuladas por la secuencia temporal: la primera ocurre en el atardecer; la segunda, durante la noche y la tercera por la mañana. El director nos proporciona el testimonio de las relaciones interpersonales en el contexto de una sociedad tan pacata como la de la época. Las relaciones se complican, entre otras cosas, por lo difícil que resulta la movilidad social en una sociedad mezquina, cerrada y arbitraria.

El afán por ascender en la escala social es precisamente uno de los ejes de la siguiente obra, El arte de vivir (1965). Aunque la película superó la censura, salvo pequeños detalles, encontró muchos problemas en la distribución. Se estrenó en Cataluña, pero en Madrid tardó más de tres años en poder ser exhibida. El film nos narra el proceso de transformación de un joven licenciado en Ciencias Económicas en su afán por ascender en la escala social.

La que iba a constituir una trilogía con Tiempo de amor y El arte de vivir, y que fue titulada provisionalmente Purificación, sufrió la prohibición de la censura, probablemente, como explica el propio Diamante, «a causa de los malestares provocados entre los censores por los dos primeros títulos» (Fernández Colorado, 2004: 93). 
Sex o no sex (1974) ha sido una película no muy bien entendida, como otras producciones de nuestro director. Julio Diamante se propone aquí realizar una radiografía de la sociedad española reprimida y a la vez una construcción paródica de una serie de películas de sexo más aludido que explícito, surgidas con el fenómeno del destape.

En La Carmen (1975), Julio Diamante lleva a cabo una revisión de este mito, con el referente del realismo crítico o el realismo social y atendiendo al código estético del flamenco. En este caso, según confiesa el director, «los problemas vinieron por otro lado, porque al productor lo metieron en la cárcel por otros negocios y para salvar la película tuve que pasar por un largo proceso durante años». El film estaba protagonizado por Sara Lezana y Julián Mateos, y contó con grandes intérpretes del flamenco como Enrique Morente, Rafael de Córdova y Enrique el Cojo.

Julio Diamante reconoce que es difícil encontrarse ante el personaje de Carmen y que no venga de inmediato a la mente la obra de Próspero Merimée. A él le sucedió también y pensó que no debía ignorarla ni rechazarla, sino enfrentarse a ella, darle una respuesta. En ese sentido, actualiza la historia, desposeyéndola de su cargazón literaria y exótica, transformando la España de pandereta que en ella brillante y exquisitamente se muestra, para reflejar algo más delimitado: un microcosmos dentro de la España actual, el marginado e incomprendido microcosmos del flamenco, tejiendo a su alrededor anécdotas y personajes.

El director ha explicado también que necesitaba encontrar una historia que fuera, en su espíritu, algo así como una soleá: poética y desgarrada, popular e impregnada de ese hondo sentido existencial que el flamenco encierra. Y la historia le viene sugerida un día al escuchar en un pueblo andaluz, de labios de un viejo cantaor no profesional, las coplas de Carmen Vero con el son de petenera antigua. ¿Quién podría ser hoy esa Carmen «perdición de los hombres»? ¿Seguiría suscitando pasiones tan absorbentes y terribles como las que la copla -y casi todas las letras amorosas del cante flamenco- permiten imaginar?

Con estos dos elementos: el mítico de la historia de Merimée y el más cercano de la petenera escuchada al viejo cantaor, Julio Diamante construye el personaje de una bailadora temperamental y cerebral al mismo tiempo, apasionada y fría, capaz de dejarse llevar por un momentáneo rapto de ternura o compasión pero también de mantener una línea de conducta cínica y cruel. Carmen ha conocido las miserias del hambre, de la semiprostitución a lo largo de una adolescencia de vagabundeo por ferias pueblerinas, por teatros chinos, antes de subir los peldaños que conducen al tablao primero, y luego al espectáculo que tal vez la transforme en una estrella. Carmen vive, en definitiva, en una continua defensa de sí misma y de lo más profundo que hay en sí misma: su arte. A él supedita todo lo demás, incluyendo sus relaciones con los hombres. 
En el contexto del misterioso arte del flamenco se inscribe también su film para televisión Vicente Escudero (1968). Escudero, que actuó, entre otras películas, en la de Mario Camus, Con el viento solano, basada en la obra homónima de Ignacio Aldecoa, fue uno de los más importantes bailarines y coreógrafos del flamenco. Julio Diamante, un importante conocedor y un entusiasta admirador de esta arte, ha sabido plasmar todas las potencialidades expresivas del baile de Vicente Escudero.

Además de su afición al flamenco, Julio Diamante siente una gran pasión por el mundo del jazz, y un gran intérprete de esta arte, Jordi Sabatés, realizó el acompañamiento musical de su corto, de $16 \mathrm{~mm}$, Antes del desayuno (1954). La fotografía corrió a cargo de Carlos Saura, y el mismo Saura, junto a Matilde Francoy, Sonsoles Gutiérrez, Carmen Vinyas y el propio Julio Diamante, entre otros, intervinieron como actores en el film. La trama de esta obra experimental, en blanco y negro, puede resumirse en lo siguiente: un hombre se detiene un instante en el proceso de su afeitado y muere al comprender que no puede seguir soportando a su mujer. Al director le interesa más la sicología de los personajes que su apariencia física, y debido a ello en esta simplificación de la interpretación se impone los siguientes objetivos: $1^{\circ}$ ) el rostro de los actores no se verá en ningún momento; $2^{\circ}$ ) cada uno de los protagonistas será interpretado por tres personas diferentes: "Se debe a esta característica el que en la cabecera del guión y a continuación del título haya puesto como definición del ensayo la un tanto marinettiana de Drama formal de objetos y fragmentos" (Diamante, 1995). Según el director, Antes del desayuno abre y cierra el periodo experimental de su carrera. Después quiso acercarse a las teorías de Brecht y Piscator, que tan inmejorable resultado habían ofrecido en el ámbito escénico: «Me interesaba un cierto expresionismo, no tanto metafísico sino político, que el teatro de Brecht o la narrativa de Kafka reflejaban con enorme audacia» (Fernández Colorado, 2004: 92).

Julio Diamante, al estrenarse Antes del desayuno, explica en el Programa del Cine-Club Universitario de Madrid que, al confeccionar el guión, comenzó por dividirlo en cinco partes, correspondientes a otras tantas variaciones que el ritmo del film había de experimentar: $1^{\circ}$ Ritmo descriptivo de comienzo. Detenido, lento examen del más importante decorado, que ha de adquirir a lo largo de la acción el valor de personaje. $2^{\circ}$ El ritmo se aligera. Se inicia la acción dramática. Exposición del problema, que finaliza cuando ella le entrega los útiles de afeitar. $3^{\circ}$ Unos momentos de descanso, tras los cuales el ritmo comienza a aumentar paulatinamente, pero sin llegar a hacerse rápido. Todo el film debe conservar un cierto estatismo. $4^{\circ}$ Con un ritmo tranquilo, tiempo medio, la mujer cesa en su trabajo y se dirige al cuarto de baño. $5^{\circ}$ Los objetos son mudos e impasibles 
testigos de la tragedia desarrollada. La intención del director no era tanto narrar un suceso cuanto describir y producir una sensación. El montaje adquiría un papel capital. Había que alcanzar una tensión dramática valiéndose exclusivamente de recursos dinámicos y a su vez estos debían ser concebidos en función de la personalidad de los dos personajes. Las metáforas son sencillas y directas, jugando siempre con elementos próximos: la leche, la cafetera exprés, los grifos, la cocinilla cubierta de cáscaras de huevo, el manómetro...

Mayor complejidad adquieren las metáforas en El proceso (1955), el mediometraje de 16 mm., en blanco y negro, mudo. Como explica Joaquín de Prada, sería pertinente volver a los gloriosos años veinte del siglo XX para lograr asimilar en su totalidad esta corta película de Diamante. La época dorada en la que el cine conquista su propia expresividad, cuando se pensaba en el cine como un nuevo lenguaje para librarnos de la esclavitud de la palabra. Tres notas hay en El Proceso de Diamante que nos hacen evocar aquella época: su cerebralismo, su búsqueda de una expresividad puramente cinematográfica -imagen, movimiento- y el «cargamento de literatura». Estamos ante el cine puro, en el sentido primitivo de este término, pues el silencio de la palabra deja sola a la imagen en la tarea de servirnos de medio de expresión.

El Proceso no es la primera adaptación literaria que realiza Diamante, como se ha expuesto con anterioridad, y de forma similar a como sucede con la obra de Fernández Flórez, el director más que transcribir fielmente el texto de Kafka, intenta sugerirnos, con un lenguaje distinto, parecidas sensaciones a las suscitadas por el autor literario. Joaquín de Prada utiliza el símil de René Claire y observa que Diamante se acerca a Kafka como Strauss pudo acercarse al Don Juan para componer su poema sinfónico. De forma similar, Diamante ha orquestado en una sinfonía de imágenes unos cuantos temas kafkianos. Pueden distinguirse, así, en el film varios «tiempos» (el del abogado, el del proceso, el de la catedral, etc.), con unidad propia e independiente. Al unirse y articularse estos tiempos entre sí, confieren a la película una unidad nueva, casi musical. Entre los mejores aciertos de esta trasposición fílmica señalan los críticos el primer tiempo, con la tristeza del protagonista, la ironía, el humor negro de algunos detalles y el delicado aire de danza que el director ha sabido imprimir a toda la escena. Resulta igualmente brillante la parte del proceso, resaltando la defensa desesperada del protagonista, de una visualidad extraordinaria, así como el último plano, de gran fuerza expresiva (Prada, 1955).

Más que trasposición es también inspiración el corto La lágrima del diablo, basado en un cuento de Teófilo Gautier, que constituiría la práctica final de diplomado en el Instituto de Investigaciones y Experiencias Cinematográficas. El proyecto inicial era ofrecer la imagen documental de las actividades del padre 
José María de Llanos en el Pozo del Tío Raimundo, uno de los barrios más deprimidos del Madrid de aquella época y de años posteriores. Rodó varios días, con Mario Camus como ayudante, pero le sugirieron desde la dirección de la Escuela que abandonase ese asunto y se decidió por la adaptación del relato de Gautier. El propio Julio Diamante ha declarado que con este film no se propuso elaborar una obra trascendente donde expresar su personal visión de las cosas ni tampoco emprender búsquedas formales, sino realizar un ejercicio académico, y como tal debe considerarse. Julio Diamante no oculta su simpatía por los románticos, lo que explica la elección de ese texto de Gautier, pero considera que en nuestros días el romanticismo no puede tomarse excesivamente en serio. Por este motivo abordó con gran libertad la historia de la obra, introduciendo en ella, por ejemplo, el componente del humor. Este equilibrio de lo sentimental y de lo humorístico está muy bien logrado, y los personajes, dentro de su contextura fantástica, aparecen humanizados por una cierta ternura.

Si se trata de buscar en la película un significado, el director sólo encuentra éste: el bien y el mal no son términos antagónicos, y aquél nunca es tan bueno ni éste tan malo. Estamos ante una moraleja bastante vaga, pero que a veces conviene recordar. El corto, además de su valor artístico, encierra un eminente sentido ético, que constituye, como toda la obra de Diamante, una importante contribución a la memoria de esos años.

\section{BIBLIOGRAFÍA}

AUB, Max (1969), Poesía española contemporánea, México, Era.

DIAMANTE, Julián (2007), Mis recuerdos de la guerra civil española, Madrid, Ministerio de Trabajo y Asuntos Sociales.

DIAMANTE, Julio (1955), «Antes del desayuno», Programa del Cine-Club Universitario de Madrid, Madrid.

- (2004) Blues jondo, Cádiz, Diputación de Cádiz.

- (2007), «Introducción. Recuérdalo tú». En Julián Diamante (2007). Mis recuerdos de la guerra civil española, Madrid, Ministerio de Trabajo y Asuntos Sociales, 11-47.

FERNÁNDEZ COLORADO, Luis (2004), «Julio Diamante, la memoria insurgente», Revista de Historia del Cine, 19 (2004), pp. 90-94.

MARTÍNEZ, Régulo (1977). Republicanos de catacumbas, Madrid, Ediciones 99.

PRADA, Joaquín de (1955), "El proceso" de Julio Diamante, en el Programa de las Primeras Conversaciones Cinematográficas Nacionales, Salamanca.

RIDRUEJO, Dionisio (1976), Casi unas memorias, Barcelona, Planeta. 
TUÑÓN DE LARA, Manuel (1988), "El poder y la oposición”, en Historia de España, dirigida por Manuel Tuñón de Lara, vol. 10: España bajo la dictadura franquista (1939-1975), pp. 167-431.

- (1989), "La rebeldía universitaria (febrero de 1956) (documentos)" y "Los sucesos del 1 al 16 de febrero de 1956, según la versión policial”, en Historia de España, dirigida por Manuel Tuñón de Lara, vol. 12: Textos y documentos de historia moderna y contemporánea (siglos XVIII-XX), pp. 569-579 y pp. 579-584".

ZUNZUNEGUI, Santos (2005). Los felices sesenta. Aventuras y desventuras del cine español (1959-1971), Barcelona, Paidós.

Fecha de recepción: 20 de mayo de 2008

Fecha de aprobación: 15 de octubre de 2008 